\title{
偏載荷重を受ける単層ラチスドームの座屈応力度と座屈荷重に関する研究 \\ BUCKLING STRESS AND BUCKLING LOAD OF SINGLE LAYER RETICULATED DOMES UNDER NON-UNIFORM LOADINGS
}

\author{
加藤 史 郎*，金 鍾 敏**，仁保 裕** \\ Shiro KATO, Jong-Min KIM and Yutaka NIHO
}

\begin{abstract}
The authors presented a proportioning method for member sections of single layer reticulated domes in the previous papers based on a second-order elastic analysis. In the first part of the present paper, a method complementary to the above method is proposed based on linear buckling stress obtained from linear buckling analysis, being more familiar than the second-order elastic analysis. The proportioning method based on linear buckling stress is verified through elasto-plastic simulation for roller supported single layer reticulated dome. The second part of the present paper discusses buckling stresses and buckling loads of single layer reticulated domes under non-uniform loadings. The usefulness of this proportioning method under non-uniform loadings is discussed and verified through elasto-plastic simulation for roller supported single layer reticulated domes.
\end{abstract}

Keywords : single layer reticulated dome, proportioning method for member sections, generalized slenderness ratio, buckling stress, elasto-plastic buckling, non-uniform loading 単層ラチスドーム, 断面算定法, 正規化細長比, 座屈応力, 弾塑性座屈, 偏載荷重

\section{1. まえがき}

単層ラチスドームの設計では座屈が重要な問題 ")となる。その座 屈性状はドームの形状, 支持条件, 接合部特性, 構成部材の細長比, 部材半開角, 形状初期不整, さらに, 荷重条件にも強く影響される。 これらの影響については様々な研究が行われ，単層ラチスドームの 力学的挙動は明らかになりつつある ${ }^{1.2) 。 ~}$

荷重状態によっては, 座屈性状が異なると想定されるものの, 従来 の研究では, 固定荷重や等分布積雪荷重に比例するような, 等分布状 の荷重を想定したものが多く, 偏載荷重を受ける場合の座屈荷重 ${ }^{31}$ 部材座屈応力度 ${ }^{4.5)}$ に関する分析はほとんど進んでいない。

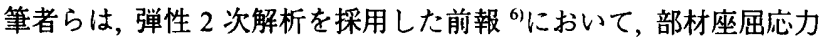
度を採用して固定荷重比例型の等分布状の荷重を受ける扁平単層ラ チスドームの断面算定法を検討し, 限られた範囲ながらその断面算 定法の有用性を議論した。しかし, 等分布荷重以外の荷重について, その有用性は未検討である。

そこで, 本研究では, 偏載荷重を受ける単層ラチスドームの断面算 定法を検討するための準備計算として偏載荷重を受ける単層ラチス ドームの座屈荷重と座屈応力度を検討する。このため, (1)周辺ローラ 一支持の扁平な単層ラチスドームに限定し，(2)等分布荷重を受ける 場合と偏載荷重を受ける場合に执いて, ラチスドームの線形, 弾性,
弾塑性座屈荷重がどう異なるか, また, (3)座屈荷重を部材座屈応力度 として評価する場合に, 座屈応力度がどう異なるかに焦点を当てて, 研究を進める。(4)等分布荷重と偏載荷重を受ける場合の座屈荷重の 違い等を検討するに当たり，どのような形状や網目，また，部材特性 を検討対象にするかが, ひとつの問題となるが,ここでは, 等分布荷 重に対して断面算定されたドームを対象とする。また, (5)断面算定法 として, 先に示した弾性 2 次解析法を採用する方法も考えられるが, この方法は, 断面算定に関する精度が確保されるものの非線形解析 が必要となり, 繰り返し計算のいる断面算定法としては, 計算効率性 がやや低い。そこで, 弾性 2 次解析よりも一般化していると考えられ る幾何剛性マトリックス法により線形座屈荷重を求め,これから得 られる線形座屈応力度を採用して断面算定を進める。

なお, 等分布荷重と偏載荷重等の複数の荷重を同時に考慮して断 面算定する方法等についての考察は今後の問題としたい。

\section{2. 解析モデル}

2.1 ラチスドームの分割数, 部材半開角, 部材細長比, 境界条件

解析モデルは, 図 1 に示す形状に限定する。ラチスドームの規模は 稜線(図 1 の $A O D, B O E$ 等)の部材数 $n$ で表され, $n$ が 12, 最大スパン約 $60 \mathrm{~m}$ 程度の円形平面とする。むくりの度合いを表す部材半開角 $\theta_{0}$ は
* 豊橋技術科学大学建設工学系 教授・工博

** 豊橋技術科学大学機械・構造システム工学専攻 大学院生·工修
Prof. Dept. of Architecture and Civil Engineering Faculty of Engineering, Toyohashi University of Technology, Dr. Eng.

Graduate Student, Mechanical \& Structural System Engineering, Toyohashi University of Technology, M. Eng. 


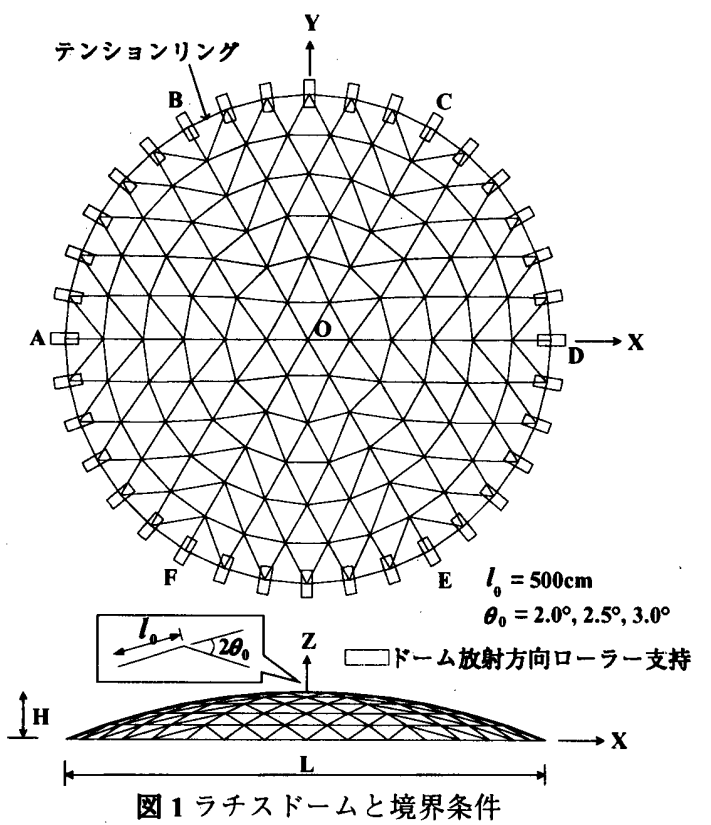

$2.0^{\circ}, 2.5^{\circ}, 3.0^{\circ}$ について検討する。

部材は銷管(弾性定数 $\mathrm{E}=206 \mathrm{KN} / \mathrm{mm}^{2}$, 降伏応力度 $\sigma_{v}=235$ $\mathrm{N} / \mathrm{mm}^{2}$ ) を想定し，節点で剛接とする。稜線の部材長さ $l_{0}$ は $500 \mathrm{~cm}$ と 固定する。したがって，ラチスドームのスパン $\boldsymbol{L}$ ，中央部の高さ $\boldsymbol{H}$, ド 一ムの曲率半径 $\boldsymbol{R}$ は表 1 となる。ラチスドーム部材の曲げ特性を表 現するため, 表 2 のように稯楾部材に対して基本細長比 $\lambda_{0}$ を設定し, これを参照し鋼管部材の標準直径 $d_{0}$ を式(1)で表す。

$$
d_{0}=2 \sqrt{2} \frac{l_{0}}{\lambda_{0}}
$$

$\lambda_{v}$ として, 40,60,80,100の場合を検討する。\$3で分かるように, この標準直径 $d_{0}$ 注1をを断面算定の初期值として用いる。また, テンシ ヨンリングの標準直径は, 内部の標準直径の 2 倍とする。したがって, 断面算定された後, 各部材の直径 $d_{i}$ は, この標準直径と異なると考 えてよい。なお，部材の㨝じり剛性は無視する。

境界条件は放射方向にローラー支持とし，円周方向と鉛直方向の 変位はゼロに拘束する。

表 1 ラチスドームのスペン $\boldsymbol{L}$, ライズ $\boldsymbol{H}$, 曲率半径 $\boldsymbol{R}$

\begin{tabular}{|c|c|c|c|}
\hline$\theta_{0}($ deg. $)$ & $L(\mathrm{~cm})$ & $H(\mathrm{~cm})$ & $R(\mathrm{~cm})$ \\
\hline 2.0 & 5827.26 & 619.31 & 7163.43 \\
\hline 2.5 & 5731.40 & 767.86 & 5731.40 \\
\hline 3.0 & 5615.50 & 912.29 & 4776.83 \\
\hline
\end{tabular}

表 2 設定した部材細長比 $\lambda_{0}$, 初期直径 $d_{0}$

\begin{tabular}{|c|c|c|c|c|}
\hline$\lambda_{0}$ & 40 & 60 & 80 & 100 \\
\hline$d_{0}(\mathrm{~cm})$ & 35.355 & 23.570 & 17.678 & 14.142 \\
& $(70.710)$ & $(47.140)$ & $(35.356)$ & $(28.284)$ \\
\hline
\end{tabular}

(括孤内はテンションリング材の直径を示す)

\section{2 断面算定用荷重条件}

前述したように，等分布荷重と偏載荷重を受ける場合の座屈荷重 の違い等を検討するに当たり，検討対象であるドームがどのような

注 1 ）断面表等で使用される直径 $D$ とは, $D=d+t$ の関係にある。
荷重に対して断面算定されたものかは, きわめて重要であるが, 現在 のところ等分布荷重と偏載荷重の両者に対して断面算定する方法は まだ議論されていない。したがって,ここでは, 図 2 に示す固定荷重 比例型の等分布荷重に対して断面算定されたドームを対象とする。等 分布荷重として, 鉛直下向きに周辺節点以外のすべての節点に各節 点当たり $392 K N\left(\right.$ ほほ $54.3 \mathrm{KN} / \mathrm{m}^{2}$ で, 各節点当たり $40 t f$ を作用させる。 この荷重に対して, 断面算定されたドームの耐力がこの值を満足す るように，\$3に述べる方法で断面を仮定する。

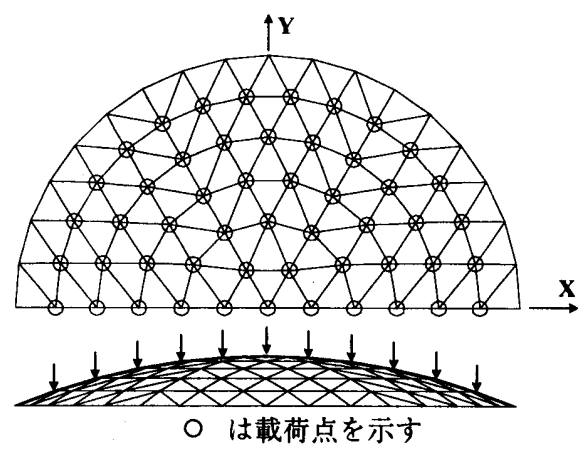

图 2 断面算定用荷重条件

\section{§3. 解析モデルの断面算定}

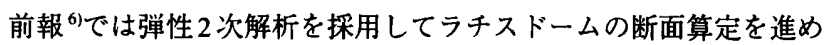
たが,ここでは, 前述のように, より一般化している幾何剛性マトリ ックスにより線形座屈荷重と線形座屈軸力を計算し，これに基づい て断面算定する。先の方法 ${ }^{6}$ と類似し多少の重複があるが, 断面算定 応力の設定の方法に異なりがあること，また，理解を容易にするため， 断面算定方法を詳述する。

\section{1 部材の初期断面の仮定}

表 1 (図1)の部材半開角 $\theta_{0}$, 表 2 の細長比 $\lambda_{0}$ の組合せで得られる 12種のラチスドームにおいて, 初期断面は次のように仮定する。構成 部材の初期值 $d_{i}$ は, 表 2 の標準値 $d_{0}$ を用い, テンションリング部材 はすべて同一で $2 d_{0}$ とする。各部材の初期管厚 $t_{i}$ は初期值として $2 \mathrm{~cm}$ とする。部材 $i$ の断面性能は, 断面の直径 $d_{i}$, 管厚 $t_{i}$ を用いて次式 で近似する。

$$
\begin{gathered}
A_{p i}=\pi \cdot d_{i} \cdot t_{i}, \quad I_{p i}=\frac{\pi \cdot d_{i}^{3} \cdot t_{i}}{8} \\
N_{p i}=\sigma_{y} \cdot A_{p i}, \quad M_{p i}=\sigma_{y} \cdot d_{i}^{2} \cdot t_{i}
\end{gathered}
$$

ここで, $A_{p i}, I_{p i}, N_{p i}, M_{p i}$ はそれぞれ, 部材 $i$ の断面績, 断面 2 次モーメント, 降伏軸力, 全塑性モーメントを表す。

\section{2 特定部材の座届応力度 ${ }^{e s} \sigma_{c r(m)}$ の仮定法}

\section{a) 既往の成果に基つく部材座屆応力度の分析}

柴田 ${ }^{51}$, 左村 ${ }^{4)}$, 仁保 ${ }^{7)}$ 等の論文では, すべての部材のうち, 線形座 屈軸力と部材降伏軸力の比, $N_{c r i}^{l i n} / N_{p_{i}}$ (i=部材番号)の值が最大とな る部材を特定部材 $(\mathrm{m})$ と称して, 部材座屈応力度の代表値として, こ の部材に対して正規化細長比 $\Lambda_{(m)}$ が定義され， $\Lambda_{(m)}$ の関数として 部材座屈応力度が計算されている。また,この部材座屈応力度とドー ムの耐力の関係が議論されている。前論文では, 部材座屈応力度(以 下, 圧縮強度)を座屈低減係数 $\alpha_{0}$ を介して修正 Dunkerley 式(3a)で表 現し，これを断面算定に用いている。座屈低減係数 $\alpha_{0}$ は線形座屈荷 重に対する弾性座屈荷重の比を表した係数である。圧縮応力度とし 


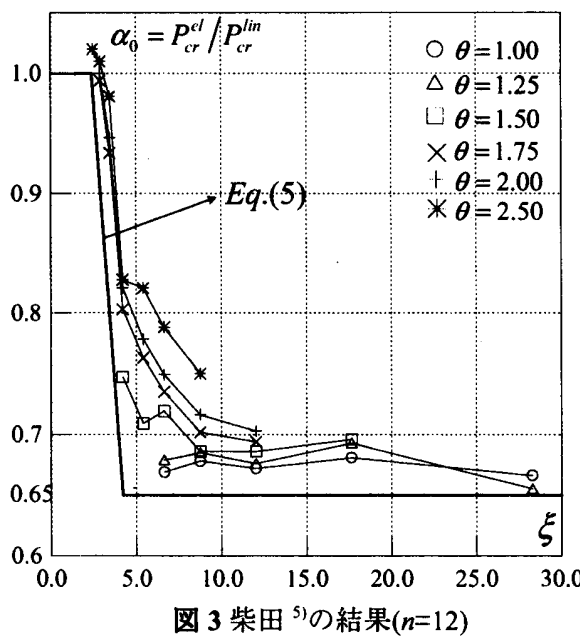

図 3 柴田 ${ }^{5)}$ の結果 $(n=12)$
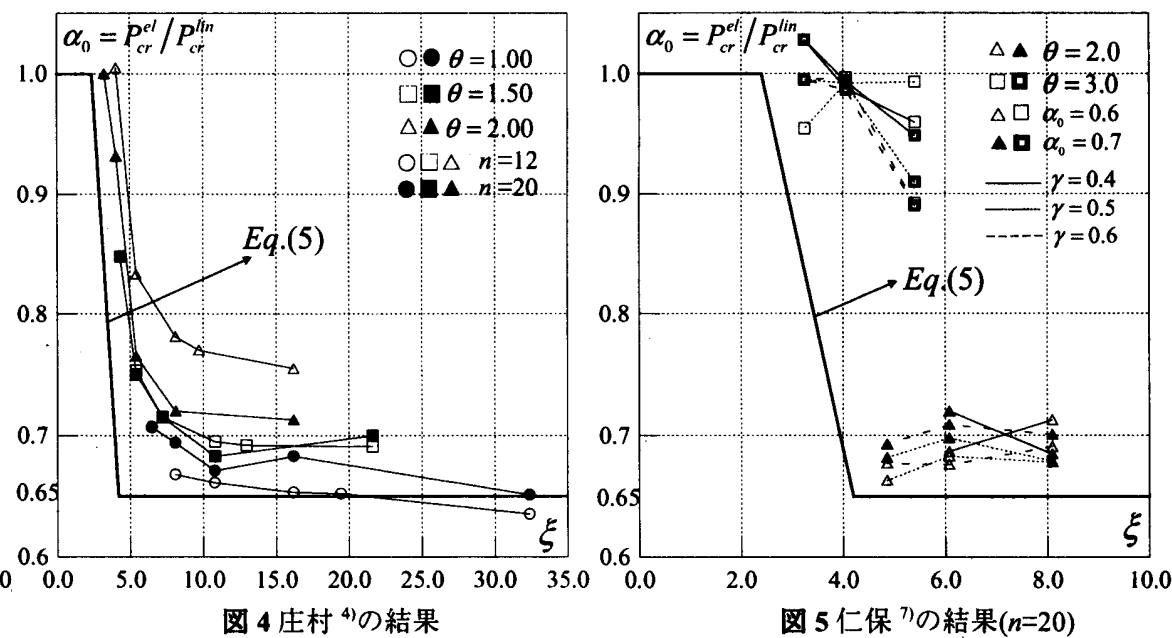

て表現すれば, 次式をうる。式(3b)は線形座屈応力度, 式(3c)は弾性 座屈応力度, 式(3d)は塑性範囲を考慮した部材座屈応力度である。

$$
\begin{gathered}
\frac{1}{\alpha_{0} / \Lambda_{(m)}^{2}}\left(\frac{{ }^{e s} N_{c r(m)}^{p l}}{N_{p_{(m)}}}\right)+\left(\frac{{ }^{e s} N_{c r(m)}^{p l}}{N_{p_{(m)}}}\right)^{2}=1.0 \\
\sigma_{c r(m)}^{l i n}=\frac{N_{c r(m)}^{l i n}}{A_{p_{(m)}}}, \sigma_{c r(m)}^{e l}=\frac{\alpha_{0} N_{c r(m)}^{l i n}}{A_{p_{(m)}}},{ }^{e s} \sigma_{c r(m)}=\frac{{ }^{e s} N_{c r(m)}^{p l}}{A_{p_{(m)}}}
\end{gathered}
$$

$(3 \mathrm{~b}, \mathrm{c}, \mathrm{d})$

既往の結果(図 3,4,5)に基づいて, 座屈応力度曲線に用いる $\alpha_{0}$ を 補助变数 $\xi$ との関係を分析》すると, 以下のような経験式が得られ る。

$$
\begin{aligned}
& \xi=\frac{12 \sqrt{2}}{\lambda_{0} \theta_{0}} \\
& 4.2<\xi \quad ; \quad \alpha_{0}=0.65 \\
& 2.4 \leq \xi \leq 4.2 ; \alpha_{0}=0.65+0.35 \frac{(4.2-\xi)}{1.8} \\
& \xi<2.4 ; \alpha_{0}=1.0
\end{aligned}
$$

本論文では, 座屈応力度の計算では, 上記を用いる。

b) 線形座届解析

線形座屈解析としては, 幾何剛性マトリックス法を採用する。た だし, 座屈荷重の精度を確保するため, 1 部材 2 要素に分割して計算 する。節点荷重から作成される荷重マトリックス $\left\{P_{\text {utd }}\right\}$ に対して 線形解析(6a)を実施し, 変位 $\left\{D_{0}\right\}$ を求め, これから部材の軸力 $N_{i}$ を計算する。この部材軸力を用いて幾何剛性マトリックス $\left[K_{G}\left(N_{i} / l_{i}\right)\right]$ を計算し, 式(6b)の線形座屈式を解き, 固有值 $\lambda$ を求 め, 最小固有值 $\lambda_{c r}^{l i n}$ に対して線形座屈軸力を求める。

$$
\begin{gathered}
{\left[K_{E}\right]\left\{D_{0}\right\}=\left\{P_{u l d d}\right\}} \\
{\left[K_{E}\right\}[D\}=\lambda\left[K_{G}(N / l)\{D\}\right.} \\
\lambda_{1}<\lambda_{2}<\lambda_{3} \ldots \ldots \lambda_{n} ; \lambda_{1}=\lambda_{c r}^{l i n}
\end{gathered}
$$

先に述べたように, 圧縮部材の内, 線形座屈軸力と部材降伏軸力の 比, $N_{c r i}^{l i n} / N_{p_{i}}$ の値が最大となる部材を特定部材 $(\mathrm{m})$ として, 特定部
材 $(\mathrm{m})$ に対して定められた座屈応力度を部材のすべてに探用する。 このようにすべての圧縮部材に共通して同じ座屈応力度を仮定する と, 断面算定過程は単純化されるが, 果たしてラチスドームの弾塑 性座屈荷重(以下, 耐力)が妥当なものとなるかについての検討が必 要となる。この検討は，\$5において検討する。

\section{3 断面力 $N_{i}^{*}, M_{i}^{*}$ の計算方法}

前報では算定用応力 $N_{i}^{*}, M_{i}^{*}$ を弾性 2 次解析によって幾何学的非 線形性を考慮して計算したが, 本報では線形弾性解析による式(6a)か ら求められる部材 $の$ 軸力 $N_{i}$, Y 軸とZ軸についての部材両端の曲げ モーメント $M_{y i}, M_{z i}$ を用いて, 次のように設計用応力 $N_{i}^{*}, M_{i}^{*}$ を計算する。i部材の軸力が圧縮力の場合は, 式(3)と(5)で表される特 定部材 $(\mathrm{m})$ の線形座屈応力度 $\sigma_{c r(m)}^{l i n}$ と弾性座屈低隇係数 $\alpha_{0}$ を用いて, 式(7)により計算する。

$$
M_{y i}^{*}=\frac{M_{y i}}{1-\frac{N_{i}}{\alpha_{0} \sigma_{c r(m)}^{l i n} A_{p i}}}, M_{z i}^{*}=\frac{M_{z i}}{1-\frac{N_{i}}{\alpha_{0} \sigma_{c r(m)}^{l i n} A_{p i}}}, N_{i}^{*}=N_{i}
$$$$
\text { 但し, } \sigma_{c r(m)}^{l i n}=\frac{N_{c r(m)}^{l i n}}{A_{p(m)}}, \sigma_{c r(m)}^{e l}=\alpha_{0} \sigma_{c r(m)}^{l i n}
$$

$i$ 部材の軸力が引張力の場合は次式によって算出する。

$$
M_{y i}^{*}=M_{y i}, \quad M_{z i}^{*}=M_{z i}, \quad N_{i}^{*}=N_{i}
$$

$(8 \mathrm{a}, \mathrm{b}, \mathrm{c})$

\section{4 断面算定用最小断面力の設定}

設計用最小断面力 $N_{\min }, M_{\min }^{*}$ は次のように設定する。

$$
\begin{gathered}
N_{\min }=\gamma \cdot \max \left(\left|N_{i}\right|\right) \\
M_{\min }^{*}=\gamma \cdot \max \left(\left|M_{i}^{*}\right|\right) \\
\text { 但し, } M_{i}^{*}=\sqrt{\left(M_{y i}^{*}\right)^{2}+\left(M_{z i}^{*}\right)^{2}}
\end{gathered}
$$

構造物の形態によっては応力が極端に小さい部材が生じる。この ような応力をそのまま設計に用いると極端に剛性の小さな部材が生 じる。このような事態かおこるのを防ぐためである。

また, $M_{i}, M_{i}^{*}$ は1つの部材の部材に対して両端で2つ計算される が,この内大きい方を用いる。 $\gamma$ は設計用最小断面力係数であり， 本研究では, 0.4, 0.5の2種について検討している。 


\section{5 断面算定用断面力の設定}

設計用断面力 $N_{d i}, M_{d i}^{*}$ は次に式により設定する。

$$
\begin{aligned}
N_{d i} & =f_{0} \cdot \max \left(\left|N_{i}\right|, N_{\min }\right) \\
M_{d i}^{*} & =f_{0} \cdot \max \left(M_{i}^{*}, M_{\min }^{*}\right)
\end{aligned}
$$

ここで， $f_{0}$ は断面算定に関する影響係数であり，部材に圧縮力が作 用する時 $f_{0}=1.0$, 部材に引張力が作用する時 $f_{0}=1.2$, ただし, テ ンションリング材は $f_{0}=1.4$ と仮定する。これは引張部材の接合部 の断面欠損等に対する漸定的な配慮から仮定したものである。

\section{6 断面の管厚と直径の变更方法}

a) 強度相関式による断面算定

部材の断面性能は式(2)より管厚 $t_{i}$ の関数として表されているので, 断面の主な修正対象は管厚 $t_{i}$ である。部材算定用の軸力は線形解析 の結果 $N_{d i}$ を, 曲げモーメントについては幾何非線形の影響を考虑 し設計用応力 $M_{d i}^{*}$ をそれぞれ用いる。各部材の管厚 $t_{i}$ の修正方法は 次式の強度相関式を滿足するように管厚算定指標 $f_{i}$ を求める。

$$
\left(\frac{N_{d i}}{f_{i} N_{p i}}\right)^{2}+\frac{M_{d i}^{*}}{f_{i} M_{p i}}=1.0
$$

\section{b) 座届判定}

圧縮部材については付帯条件として, 部材軸力に対して座屈判定 を行う。式(3)によって求めた特定部材 $(\mathrm{m})$ の座屈応力度 ${ }^{e s} \sigma_{c r(m)}$ を 用いて座屈判定式(12)を滿足するように管厚算定指標 $f_{i}$ を求める。

$$
\left|\frac{N_{i}^{*}}{f_{i}{ }^{e s} \sigma_{c r(m)} A_{p i}}\right|=1.0, \quad f_{i}=\left|\frac{N_{i}^{*}}{{ }^{e s} \sigma_{c r(m)} A_{p i}}\right|
$$

\section{c) 直径, 管厚の修正}

引張部材の場合は式(11)から計算される $f_{i}$ を用いる。圧縮部材 については式(11)と(12)の式から $f_{i}$ を計算し，大きい方を採用する。 この管厚算定指標 $f_{i}$ を用いて次式で管厚 $t_{i}$ を修正する。

$$
t_{i} \leftarrow f_{i} \cdot t_{i}
$$

また，管厚 $t_{i}$ が直径 $d_{0}$ に対して異常に大きくなる場合には非現実 的な断面になるため, 式(14a)の制約条件式を満たす場合，やはり漸 定的な配慮として式(14b)の操作で直径 $d_{i}$ を変更する。

$$
t_{i} \geq 0.2 d_{i}, \quad d_{i} \leftarrow 1.1 d_{i}
$$

$(14 a, b)$

\section{d) 收束判定}

式(13)で管厚 $t_{i}$ を算定し，それを再び管厚 $t_{i}$ として收束計算を行 う。全ての構成部材について收束判定指標式(15)を満足するまで式 (2)に戻り繰り返し計算する。

$$
0.98 \leq f_{i} \leq 1.02
$$

\section{4. 断面算定されたドームの耐カの分析 \\ 4.1 部材断面の分布}

S3 で述べた方法で得られた断面の一例を図 6 に示す。図には, ドーム内部の部材の内, 最大管厚を基準として正規化した分布を示 す。ただし,テンションリングについては，数字のみ示す。前報と 同样に稜線部材(図 1 の $A O, O B, O C, O D, O E, O F$ )が他の部材よりも管厚 が大きい結果となっている。図 6 の部材上円の中の小さい円は直径
の変更がみられた部材を示す。結果の図は省略するが, $\theta_{0}=2.0^{\circ}$, $2.5^{\circ}$ の場合は $\lambda_{0}=80,100$ で, $\theta_{0}=3.0^{\circ}$ の場合は $\lambda_{0}=100$ で, 内部 の部材の直径に変更が見られる。また， $\theta_{0}=3.0^{\circ}, \gamma=0.4, \lambda_{0}=$ 100 については収束しなかった。

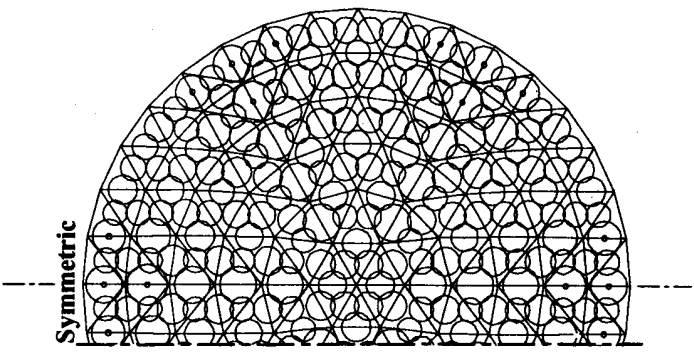

$t_{\text {min }}=1.78 \mathrm{~cm}, t_{\max }=2.97 \mathrm{~cm}, t_{\text {ring }}=6.26 \mathrm{~cm}$

$d_{\min }=17.678 \mathrm{~cm}, \quad d_{\max }=19.445 \mathrm{~cm} \quad\left(d_{0}=17.678 \mathrm{~cm}\right)$ $d_{\text {ring }}=35.356 \mathrm{~cm} \quad\left(d_{0 \text { ring }}=35.356 \mathrm{~cm}\right)$

图 6 管厚分布 $\left(\theta_{0}=2.5^{\circ}, \lambda_{0}=80, \gamma=0.5\right)$

\section{2 弾塑性座届荷重}

断面算定されたドームが果たして所定の耐力(各節点当たり $392 K N)$ を有するかどうか検討するため, 弾塑性座屈解析を実施し, 耐力(弾塑性座屈荷重) $P_{c r}^{p l}$ を求めた。解析法は, 前報6)と同様であ り, 詳細は省く。部材のモデルは, 図 7 に示すものであり，部材の 両端と部材の中央に部材降伏を表現するバネが設定されたものであ る。部材半開角, 標準部材細長比毎に結果を表 3 に示す。

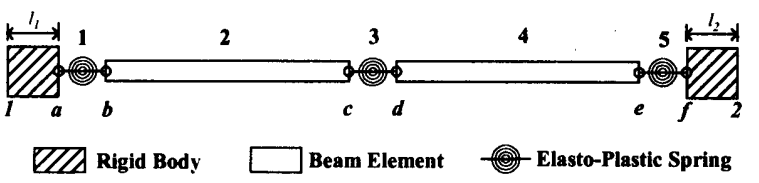

图 7 部材モデル

表 3 弾塑性座屈荷重 $(K N /$ node $)$, ラチス材の最大, 最小管厚

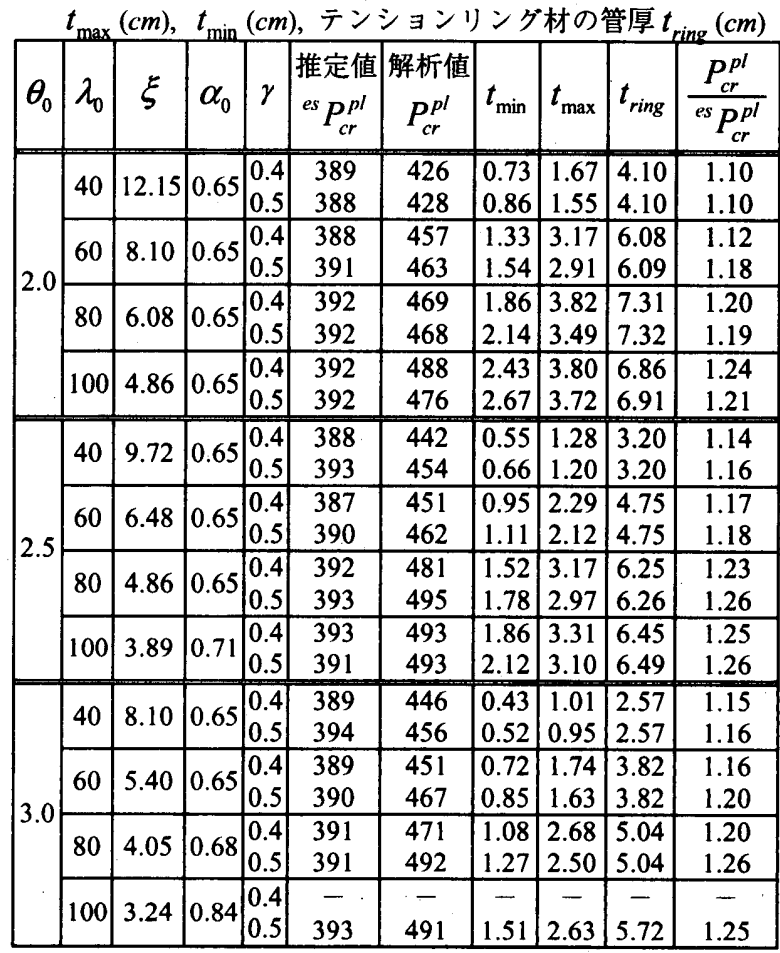

(但し, 設計荷重 $P_{\text {uldd }}=392 \mathrm{KN} / \mathrm{hode}$ ) 
表 3 の ${ }^{e s} P_{c r}^{p l}$ は, 式(5)の $\alpha_{0}$ と特定部材(m)の $\Lambda$ を式(3a)に代入し て得られる部材座屈応力 ${ }^{e s} N_{c r(m)}^{p l}$ を用いて, 次式で計算した耐力 (弾塑性座届荷重)の推定値である。

$$
{ }^{e s} P_{c r}^{p l}=P_{u l t d} \cdot\left({ }^{e s} N_{c r(m)}^{p l} / N_{(m)}\right)
$$

ここで, $N_{(m)}$ は設計荷重 $P_{\text {uld }}$ に対する線形弾性解析から求めら れる特定部材の軸力を示す。

表 3 に示すように,すべての場合にわたり，断面算定されたドー ムの耐力 $P_{c r}^{p l}$ は, 設定した節点荷重 $P_{\text {uld }}=392 K N$ を満たしている。 推定された值と解析值の関係は\$5.3で検討する。

\section{§5. 偏載荷重を受けるドームの座届荷重の分析}

等分布荷重に対して断面算定されたラチスドームが偏載荷重を受 けると, その座屈荷重は等分布の場合からどう変動するかを分析す る。線形座屈は, \$3.2 の幾何剛性を用いた結果であり，弾性座屈と 弾塑性座屈荷重は, 84.2 と同じ方法による結果である。

\section{1 偏載荷重の仮定, 境界条件等}

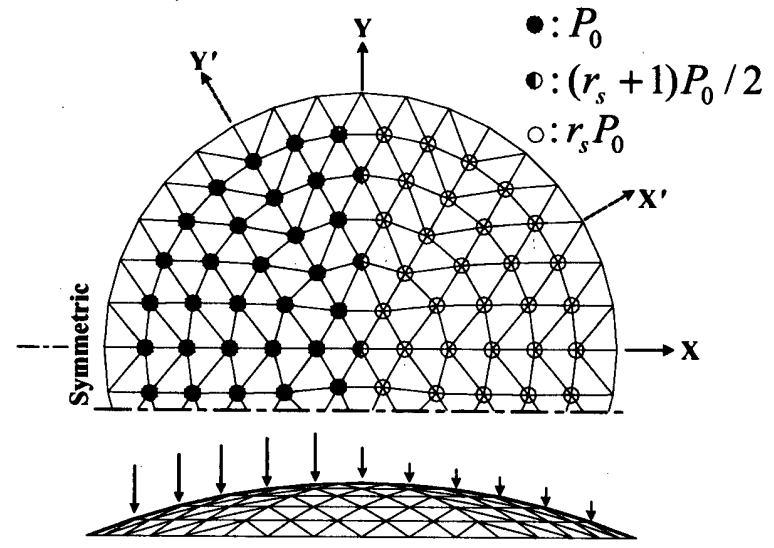

因 8 偏載荷重の仮定 $\left(P_{0}=392 \mathrm{KN} /\right.$ node, $\left.r_{s}=1 / 4,2 / 4,3 / 4,4 / 4\right)$

偏載荷重を受けるドームの形状と境界条件は図 1 の断面算定の解 析モデルと同じものである。但し, 設計用最小断面力係数は表 3 の $\gamma=0.5$ を用いたものである。

ラチスドームの耐力は, 作用する荷重形態に大きな影響を受ける。 本研究では, 積雪の荷重を想定し, 図 8 に示すように鉛直下向きと する。荷重の偏載度を $r_{s}$ で表記し, $r_{s}$ が $1 / 4,2 / 4,3 / 4$, 及び等分布と なる $4 / 4$ について, 検討する。基準荷重 $P_{0}$ は392KN/node と設定する。

なお，図 8 の $\mathrm{X}^{\prime}, \mathrm{Y}^{\prime}$ を対称軸とする偏載荷重分布(図 Al)に対する 結果は図 8 の荷重分布の場合とほほ同じ傾向であり, 詳細は省略し,

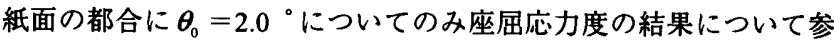
考として Appendix に示す。

\section{2 解析結果}

解析䊅果を表 4 に示す。 $\alpha_{0}$ は補助变数 $\xi$ 関数で式(5)で計算し た值である。 $\Lambda$ と $\Lambda_{e}$ は，それぞれ，式(17a)と式(17b)を用いて，特 定部材 $(\mathrm{m})$ の線形座屈軸力から計算される正規化細長比である。

$$
\Lambda=\sqrt{\frac{N_{p_{(m)}}}{N_{c r(m)}^{l i n}}}, \quad \Lambda_{e}=\sqrt{\frac{N_{p_{(m)}}}{\alpha_{0} N_{c r(m)}^{l i n}}}
$$

表4の ${ }^{e s} N_{c r(m)}^{p l} / N_{p_{(m)}}$ は， $\alpha_{0}$ と $\Lambda$ を式(3a)に代入して得られる
值である。解析から得られる線形, 弾性, 及び弾塑性の座屈荷重を, $P_{c r}^{l i n}, P_{c r}^{e l}$ およ゙ $P_{c r}^{p l}$ として示す。

また, 図 9,10には, 正規化細長比 $\Lambda$ あるいは $\Lambda_{e}$ を横軸に, 特定 部材 $(\mathrm{m})$ の座屈軸力(座屈応力)を縦軸にして, その関係を示す。座屈 軸力は, 数值解析から計算された弾性座屈荷重 $P_{c r}^{e l}$, 弾塑性座屈荷 重 $P_{c r}^{p l}$ から, 次式で定める。一般には, 非線形性のため軸力と荷重 は線形関係にはないが,ここでは, 座屈荷重の表現として弾性及び 弾塑性の座屈荷重を次式を援用して表現したものである。

$$
\begin{aligned}
& N_{c r}^{e l}=P_{c r}^{e l} \cdot\left(N_{(m)} / P_{0}\right) \\
& N_{c r}^{p l}=P_{c r}^{p l} \cdot\left(N_{(m)} / P_{0}\right)
\end{aligned}
$$

\section{3 結果の分析}

\section{a) 偏載度による座屆荷重の変化}

荷重の偏載による線形座屈荷重と弾性座屈荷重の変化が, 表 4 の $P_{c r}^{l i n}\left(r_{s}\right) / P_{c r}^{l i n}(4 / 4), P_{c r}^{e l}\left(r_{s}\right) / P_{c r}^{l i n}(4 / 4)$ で示される。 $r_{s}=1 / 4$ の場 合, $P_{c r}^{l i n}(1 / 4)$ は $P_{c r}^{l i n}(4 / 4)$ の $85 \%$ 程度に低下する。弾性座屈荷重 $P_{c r}^{e l}(4 / 4)$ が $P_{c r}^{l i n}(4 / 4) の 60 \sim 80 \%$ 程度であったものが, $P_{c r}^{e l}(1 / 4)$ は, $P_{c r}^{\text {lin }}(4 / 4) の 50 \%$ 程度まで低下する。

$r_{s}=1 / 4$ の場合, 座屈荷重の低隇度, $P_{c r}^{l i n}(1 / 4) / P_{c r}^{l i n}(4 / 4)$, $P_{c r}^{e l}(1 / 4) / P_{c r}^{e l}(4 / 4), P_{c r}^{p l}(1 / 4) / P_{c r}^{p l}(4 / 4)$ は，それぞれ, $85 \%$, $85 \%, 70 \%$ 程度となり, 弾塑性座屈荷重の低下が大きい。

\section{b) 基準荷重 392KN と偏載のある場合の弾塑性座届荷重の比較}

荷重の偏載度 $r_{s}$ が $1 / 4$ では，ほとんどの場合 $\left(\theta_{0}=2.0^{\circ}\right.$ の細長比が 80 と 100 を除く場合), $P_{c r}^{p l}\left(r_{s}\right)$ は, 等分布荷重に対して要求した基 準荷重 392KN より低い。偏載荷重に対して断面を算定していない ので，すべての場合に基準荷重を満足する保証は当然にないが，偏 載度が $2 / 4$ 以上では偏載度を考慮せずに等分布荷重に対して断面算 定したドームであっても, 基準荷重を渵たしている。しかし, 偏載度 $r_{s}$ が 1/4 で基準荷重を满たしていないという事実は, 多雪地域のよ うに偏載雪荷重の考慮が必要な地域，あるいは，風荷重による荷重 の偏載度がある場合, さらには, 非対称の大きな上下地震荷重を受 けるような場合には, 単に等分布荷重だけでなく荷重の偏載度を考 慮した断面算定が必要である，という至極当然な結果を示している。 c) 座届荷重低減係数 $\alpha_{0}$ の分析

等分布荷重に対して, 式(5)で定める $\alpha_{0}$ を援用して断面算定され たラチスドームに偏載荷重を作用させる。線形座屈と弾性座屈荷重 を求め, 改めて座屈荷重低減係数 $P_{c r}^{e l}\left(r_{s}\right) / P_{c r}^{l i n}\left(r_{s}\right)$ を計算した結果 を図 11 に○で示す。この結果には, 比較のため断面算定に用いた図 3,4,5の值も併せて示す。の結果は, 式(5)の值よりわずかに低めと なり, 式(5)は, 全体的には平均的な傾向を示す結果となっている。

線形座屈荷重 $P_{c r}\left(r_{s}\right)$ と座屈荷重低減係数 $\alpha_{0}$ を用いて弾性座屈 荷重を推定する場合, 本論文で断面算定したドームに適用しうる座 屈低減係数としては, 式(5)に0.8 を乗じた值を使用すれば, 本研究 で断面算定されたドームの座屈低隇係数の下界を押えることが出来 る。

\section{d) 座届応力度の分析}

弾塑性座屈荷重を特定部材 $(\mathrm{m})$ の座屈軸力に変換し, この座屈軸 力を正規化細長比の関係として表現したものが図 9である。弾塑性 座屈軸力 $N_{c r(m)}^{p l} / N_{p_{(m)}}$ を, 等分布と偏載の場合について比較する と, 図 9(表 4)に示されるように同じドームであれば偏載の場合が大 
表 4 偏載荷重を受けるドームの解析結果および荷重 $(K N /$ node $)$ の偏載による座屈荷重 $(K N /$ node $)$ の低減度 $(\gamma=0.5)$

\begin{tabular}{|c|c|c|c|c|c|c|c|c|c|c|c|c|c|c|c|c|c|c|c|}
\hline$\theta_{0}$ & $\lambda_{0}$ & $\alpha_{0}$ & $r_{s}$ & $\lambda_{c r}^{l i n}$ & $\Lambda$ & $\Lambda_{e}$ & $\begin{array}{l}\text { 推定值 } \\
{ }^{{ }^{x}} N_{c r(m)}^{p l} \\
N_{p_{(m)}}\end{array}$ & $\begin{array}{l}\text { 解析值 } \\
\frac{N_{c r(m)}^{p l}}{N_{p_{(m)}}} \\
\end{array}$ & $P_{c r}^{l i n}\left(r_{s}\right)$ & $\begin{array}{c}\text { 推定値 } \\
{ }^{e s} P_{c r}^{e l}\end{array}$ & $P_{c r}^{e l}\left(r_{s}\right)$ & $\mid \begin{array}{c}\text { 推定値 } \\
{ }^{e s} P_{c r}^{p l}\end{array}$ & $P_{c r}^{p l}\left(r_{s}\right)$ & $\frac{P_{c r}^{c l}\left(r_{s}\right)}{P_{c r}^{l i n}\left(r_{s}\right)}$ & $\frac{P_{c r}^{l i n}\left(r_{s}\right)}{P_{c r}^{l i n}\left(\frac{4}{4}\right)}$ & $\frac{P_{c r}^{e l}\left(r_{s}\right)}{P_{c r}^{l i n}\left(\frac{4}{4}\right)}$ & $\frac{P_{c r}^{e l}\left(r_{s}\right)}{P_{c r}^{e l}\left(\frac{4}{4}\right)}$ & $\frac{P_{c r}^{p l}\left(r_{s}\right)}{P_{c r}^{l i n}\left(\frac{4}{4}\right)}$ & $\frac{P_{c r}^{p l}\left(r_{s}\right)}{P_{c r}^{p l}\left(\frac{4}{4}\right)}$ \\
\hline \multirow{16}{*}{.0} & \multirow{4}{*}{40} & \multirow{4}{*}{0.65} & $1 / 4$ & \begin{tabular}{|l|}
3.37 \\
\end{tabular} & 0.53 & 0.66 & 0.81 & 1.01 & 1322 & 860 & 709 & 301 & 376 & 0.54 & 0.92 & 0.49 & 0.87 & 0.26 & 0.88 \\
\hline & & & $2 / 4$ & 3.53 & 0.56 & 0.69 & 0.79 & 0.92 & 1383 & 899 & 735 & 340 & 397 & 0.53 & 0.96 & 0.51 & 0.90 & 0.28 & 0.93 \\
\hline & & & $3 / 4$ & 3.68 & 0.58 & 0.71 & 0.78 & 0.86 & 1442 & 937 & 766 & 371 & 412 & 0.53 & 1.01 & 0.53 & 0.94 & 0.29 & 0.96 \\
\hline & & & $4 / 4$ & 3.66 & 0.60 & 0.74 & 0.76 & 0.84 & 1435 & 933 & 817 & 388 & 428 & 0.57 & 1.00 & 0.57 & 1.00 & 0.30 & 1.00 \\
\hline & \multirow{4}{*}{60} & \multirow{4}{*}{0.65} & $1 / 4$ & 2.44 & 0.65 & 0.81 & 0.72 & 0.94 & 958 & 623 & 551 & 295 & 382 & 0.58 & 0.91 & 0.53 & 0.89 & 0.36 & 0.83 \\
\hline & & & $2 / 4$ & 2.58 & 0.69 & 0.85 & 0.70 & 0.88 & 1011 & 657 & 572 & 336 & 421 & 0.57 & 0.97 & 0.55 & 0.93 & 0.40 & 0.91 \\
\hline & & & $3 / 4$ & 2.71 & 0.71 & 0.88 & 0.68 & 0.86 & 1064 & 691 & 596 & 368 & 462 & 0.56 & 1.02 & 0.57 & 0.96 & 0.44 & 1.00 \\
\hline & & & $4 / 4$ & 2.67 & 0.76 & 0.94 & 0.65 & 0.78 & 1048 & 681 & 618 & 391 & 463 & 0.59 & 1.00 & 0.59 & 1.00 & 0.44 & 1.00 \\
\hline & \multirow{4}{*}{80} & \multirow{4}{*}{0.65} & $1 / 4$ & 2.17 & 0.72 & 0.90 & 0.67 & 0.91 & 852 & 554 & 504 & 300 & 403 & 0.59 & 0.90 & 0.53 & $\begin{array}{l}0.89 \\
\end{array}$ & 0.43 & 0.86 \\
\hline & & & $2 / 4$ & 2.30 & 0.76 & 0.95 & 0.65 & 0.83 & 904 & 587 & 541 & 341 & 437 & 0.60 & 0.95 & 0.57 & 0.95 & 0.46 & 0.93 \\
\hline & & & $3 / 4$ & 2.43 & 0.78 & 0.97 & 0.63 & 0.81 & 954 & 620 & 560 & 371 & 476 & 0.59 & 1.01 & 0.59 & 0.99 & 0.50 & 1.02 \\
\hline & & & $4 / 4$ & 2.42 & 0.83 & 1.03 & 0.60 & 0.72 & 948 & 616 & 568 & 392 & 468 & 0.60 & 1.00 & 0.60 & 1.00 & 0.49 & 1.00 \\
\hline & \multirow{4}{*}{00} & \multirow{4}{*}{0.65} & $1 / 4$ & 2.05 & 0.77 & 0.96 & 0.64 & 0.88 & 803 & 522 & 526 & 306 & 417 & 0.66 & 0.89 & 0.58 & 0.94 & 0.46 & 0.88 \\
\hline & & & $2 / 4$ & 2.19 & 0.81 & 1.01 & 0.61 & 0.84 & 857 & 557 & 549 & 348 & 474 & 0.64 & 0.95 & 0.61 & 0.98 & 0.52 & 1.00 \\
\hline & & & $3 / 4$ & 2.32 & 0.83 & 1.03 & 0.60 & 0.78 & 910 & 591 & 553 & 377 & 489 & 0.61 & 1.01 & 0.61 & 0.99 & 0.54 & 1.03 \\
\hline & & & $4 / 4$ & 2.31 & 0.87 & 1.07 & 0.58 & 0.70 & 904 & 588 & 560 & 392 & 476 & 0.62 & 1.00 & 0.62 & 1.00 & 0.52 & 1.00 \\
\hline \multirow{16}{*}{2.5} & \multirow{4}{*}{10} & \multirow{4}{*}{0.65} & $1 / 4$ & 3.96 & 0.47 & 0.59 & 0.84 & 1.11 & 1554 & 1010 & 872 & 294 & 388 & 0.56 & 0.94 & 0.53 & 0.87 & 0.23 & 0.85 \\
\hline & & & $2 / 4$ & 4.16 & 0.50 & 0.62 & 0.83 & 1.01 & 1633 & 1061 & 908 & 338 & 412 & 0.56 & 0.98 & 0.55 & 0.91 & 0.25 & 0.91 \\
\hline & & & $3 / 4$ & 4.36 & 0.52 & 0.65 & 0.81 & 0.91 & 1710 & 1111 & 952 & 381 & 427 & 0.56 & 1.03 & 0.57 & 0.95 & 0.26 & 0.94 \\
\hline & & & $4 / 4$ & 4.23 & 0.55 & 0.68 & 0.80 & 0.92 & 1659 & 1078 & 1000 & 393 & 454 & 0.60 & 1.00 & 0.60 & 1.00 & 0.27 & 1.00 \\
\hline & \multirow{4}{*}{60} & \multirow{4}{*}{0.65} & \begin{tabular}{|l|}
$1 / 4$ \\
\end{tabular} & 2.70 & 0.58 & \begin{tabular}{|l}
0.73 \\
\end{tabular} & 0.77 & 1.06 & 1060 & 689 & 642 & 279 & 382 & 0.61 & 0.90 & 0.55 & 0.89 & 0.33 & 0.83 \\
\hline & & & $2 / 4$ & 2.87 & 0.62 & 0.76 & 0.75 & 0.98 & 1125 & 731 & 713 & 320 & 418 & 0.63 & 0.96 & 0.61 & 0.99 & 0.36 & 0.90 \\
\hline & & & $3 / 4$ & 3.02 & 0.66 & 0.81 & 0.72 & 0.90 & 1185 & 770 & 727 & 368 & 456 & 0.61 & 1.01 & 0.62 & 1.01 & 0.39 & 0.99 \\
\hline & & & $4 / 4$ & 3.00 & 0.69 & 0.85 & 0.70 & 0.83 & 1175 & 764 & 722 & 390 & 462 & 0.62 & 1.00 & 0.62 & 1.00 & 0.39 & 1.00 \\
\hline & \multirow{4}{*}{80} & & $1 / 4$ & 2.15 & 0.69 & 0.86 & 0.70 & 0.91 & 844 & 549 & 579 & 283 & 371 & 0.69 & 0.89 & 0.61 & 0.94 & 0.39 & 0.75 \\
\hline & & & $2 / 4$ & 2.28 & 0.74 & 0.91 & 0.67 & 0.90 & 895 & 582 & 607 & 323 & 435 & 0.68 & 0.94 & 0.64 & 0.98 & 0.46 & 0.88 \\
\hline & & 0.65 & $3 / 4$ & 2.44 & 0.78 & 0.97 & 0.64 & 0.85 & 955 & 621 & 610 & 370 & 492 & 0.64 & 1.01 & 0.64 & 0.99 & 0.52 & 0.99 \\
\hline & & & $4 / 4$ & 2.42 & 0.83 & 1.03 & 0.60 & 0.76 & 950 & 618 & 617 & 393 & 495 & 0.65 & 1.00 & 0.65 & 1.00 & 0.52 & 1.00 \\
\hline & & & \begin{tabular}{|l|}
$1 / 4$ \\
\end{tabular} & 1.82 & 0.76 & 0.91 & 0.67 & 0.92 & 714 & 508 & 517 & 279 & 383 & 0.72 & 0.84 & 0.61 & 0.91 & 0.45 & 0.78 \\
\hline & 1100 & 71 & $2 / 4$ & 2.05 & 0.79 & 0.93 & 0.65 & 0.87 & 804 & 571 & 511 & 326 & 431 & 0.64 & 0.95 & 0.60 & 0.90 & 0.51 & 0.87 \\
\hline & 100 & 0.11 & $3 / 4$ & 2.23 & 0.83 & 0.99 & 0.63 & 0.87 & 873 & 620 & 560 & 377 & 492 & 0.64 & 1.03 & 0.66 & 0.99 & 0.58 & 1.00 \\
\hline & & & $4 / 4$ & 2.16 & 0.88 & 1.05 & 0.59 & 0.75 & 846 & 601 & 568 & 391 & 493 & 0.67 & 1.00 & 0.67 & 1.00 & 0.58 & 1.00 \\
\hline & & & $1 / 4$ & 4.43 & 0.43 & 0.54 & 0.87 & 1.17 & 1737 & 1129 & 1025 & 283 & 38 & 0.59 & 0.94 & 0.55 & 0.87 & 0.21 & 0.84 \\
\hline & 40 & 0.65 & $2 / 4$ & 4.67 & 0.46 & 0.57 & 0.85 & 1.09 & 1830 & 1189 & 1072 & 325 & 41 & 0.59 & 0.99 & 0.58 & 0.91 & 0.22 & 0.95 \\
\hline & 40 & & $3 / 4$ & 4.88 & 0.49 & 0.61 & 0.83 & 0.95 & 1915 & 1245 & 1128 & 380 & 43 & 0.59 & 1.03 & 0.61 & 0.96 & 0.23 & 0.95 \\
\hline & & & $4 / 4$ & 4.73 & 0.51 & 0.63 & 0.82 & 0.95 & 1856 & 1206 & 1177 & 394 & 45 & 0.63 & 1.00 & 0.63 & 1.00 & 0.25 & 1.00 \\
\hline & & & $1 / 4$ & 2.89 & 0.54 & 0.67 & 0.80 & 1.10 & 1132 & 736 & 774 & 265 & 362 & 0.68 & 0.90 & 0.61 & 0.96 & 0.29 & 0.78 \\
\hline & 60 & 065 & $2 / 4$ & 3.10 & 0.57 & 0.70 & 0.78 & 1.05 & 1217 & 791 & 811 & 306 & 411 & 0.67 & 0.96 & 0.64 & 1.00 & 0.32 & 0.88 \\
\hline & 00 & 0.05 & $3 / 4$ & 3.28 & 0.61 & 0.75 & 0.76 & 0.95 & 1287 & 837 & 819 & 359 & 45 & 0.64 & 1.02 & 0.65 & 1.01 & 0.36 & 0.97 \\
\hline & & & $4 / 4$ & 3.22 & 0.65 & 0.81 & 0.73 & 0.87 & 1265 & 822 & 809 & 390 & 46 & 0.64 & 1.00 & 0.64 & 1.00 & 0.37 & 1.00 \\
\hline & & & $1 / 4$ & 2.04 & 0.67 & 0.81 & 0.73 & 0.99 & 799 & 542 & 556 & 256 & 349 & 0.70 & 0.86 & 0.60 & 0.86 & 0.38 & 0.71 \\
\hline & 80 & 1068 & $2 / 4$ & 2.30 & 0.68 & 0.83 & 0.71 & 0.93 & 904 & 613 & 634 & 301 & 395 & 0.70 & 0.97 & 0.68 & 0.98 & 0.43 & 0.80 \\
\hline & 80 & 0.08 & $3 / 4$ & 2.48 & 0.73 & 0.8 & 0.68 & 0.8 & 971 & 660 & 660 & 355 & 46 & 0.68 & 1.05 & 0.71 & 1.02 & 0.50 & 0.94 \\
\hline & & & $4 / 4$ & 2.37 & 0.88 & 1.00 & 0.62 & 0.78 & 928 & 630 & 647 & 391 & 492 & 0.70 & 1.00 & 0.70 & 1.00 & 0.53 & 1.00 \\
\hline & & & $1 / 4$ & 1.66 & 0.75 & 0.82 & 0.72 & 0.94 & 650 & 543 & 537 & 261 & 339 & 0.83 & 0.86 & 0.71 & 0.91 & 0.45 & 0.69 \\
\hline & & & $2 / 4$ & 1.89 & 0.76 & 0.84 & 0.71 & 0.93 & 740 & 619 & 558 & 307 & 402 & 0.75 & 0.98 & 0.74 & 0.95 & 0.53 & 0.82 \\
\hline & J & 0.84 & $3 / 4$ & 2.01 & 0.83 & 0.90 & 0.67 & 0.82 & 789 & 660 & 564 & 361 & 440 & 0.72 & 1.05 & 0.75 & 0.96 & 0.58 & 0.90 \\
\hline & & & $4 / 4$ & 1.92 & 0.92 & 1.01 & 0.61 & 0.77 & 753 & 630 & 589 & 393 & 491 & 0.78 & 1.00 & 0.78 & 1.00 & 0.65 & 1.00 \\
\hline
\end{tabular}

(但し, 設計荷重 $P_{0}=392 K N /$ node)

きい值となる。 $r_{s}=1 / 4$ の場合の值は, $r_{s}=4 / 4$ の場合值より, 10 12\% ほど高い。したがっで, 正規化細長比を横軸に $N_{c r(m)}^{p l} / N_{p_{(m)}}$ を縦軸 に表現すると, 図 9 に見られるように偏載荷重の場合の値は, 等分布 に場合に比べ,やや高めの分布となる。この結果から, 偏載荷重の場 合の座屈応力度曲線を等分布の場合の座屈曲線で代替しても, 安全 側の誤差内にあると判断できる。

\section{e) 弾塑性座屈荷重の推定値の分析}

弾塑性座屈軸力の分布は, 式(3a)において $\alpha_{0}=1.0$ とした曲線上に あるか, 曲線に示す值よりも大きい。式(5)の $\alpha_{0}$ の值は, 1.0 より小さ いから，この式(5)の $\alpha_{0}$ を式(3a)に代入して得られる座屈軸力の推定 值を援用して弾塑性座屈荷重 ${ }^{e s} P_{c r}^{p l}$ を推定すると, この ${ }^{e s} P_{c r}^{p l}$ は, 解 析から得られる弾塑性座屈荷重 $P_{c r}^{p l}$ 上りも小さな值となる。この様 子を, 表 4 の $P_{c r}^{p l}$ と ${ }^{e s} P_{c r}^{p l}$ の值を用いて示したものが, 図 12 である。
今回対象とした偏載荷重のすべての場合にあって, $P_{c r}^{p l} /{ }^{e s} P_{c r}^{p l}>1.0$ となり, 安全側に弾塑性座屈荷重を推定している。また, $r_{s}=1 / 4$ の 場合の $P_{c r}^{p l} /{ }^{e s} P_{c r}^{p l}$ の値が 1.25 から 1.4 に分布し, 等分布の場合よりも 10 20\%高めの值でより安全側となっている。この理由は; (あ) 式(5) の $\alpha_{0}$ と式(3a)のによる座屈応力度曲線が解析による值(図 9)よりもや や低いことにあること，(い）上述 d)の分析にあるように， $N_{c r(m)}^{p l} / N_{p_{(m)}}$ の值が, 偏載荷重の場合には等分布の場合に比べ, やや高めの分布となることにある。

f) 座届低隇係数を反映した正規化細長比 $\Lambda_{e}$ による座屈応力度の表 現：図 10 は, 弾性座屈軸力の推定値による正規化細長比 $\Lambda_{e}$ を横軸 にして, 座屈軸力を表示したものである。ただし， $\alpha_{0}$ は式(5)で計算 する值である。図 9 の横軸を変換したため解析結果が多少右にずれる が, 基本的には図 9 と変わりがない。 $\alpha_{0}=1.0$ とした修正 Dunkerley 式 


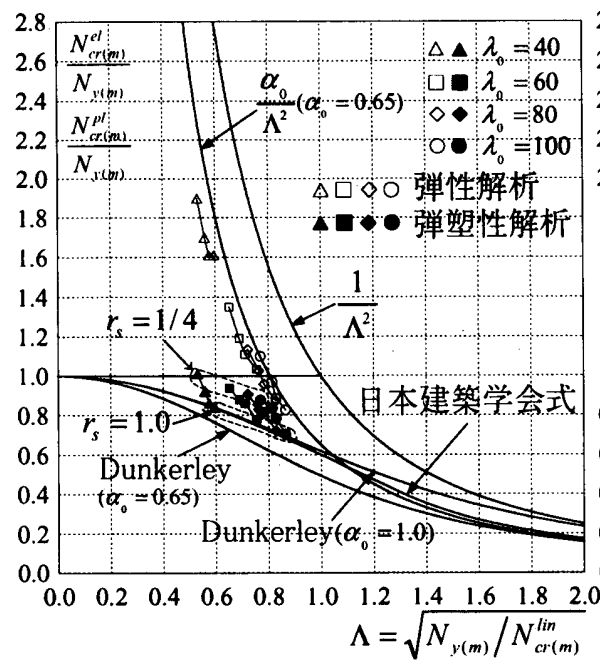

(a) $\theta_{0}=2.0^{\circ}$

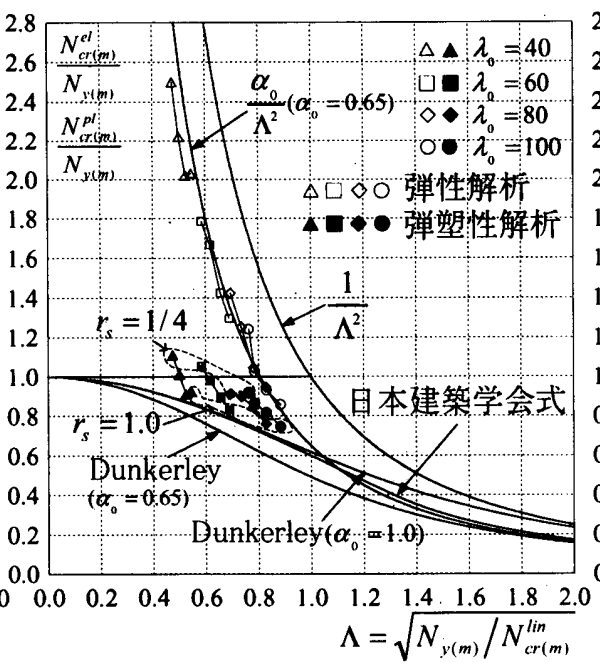

(b) $\theta_{0}=2.5^{\circ}$

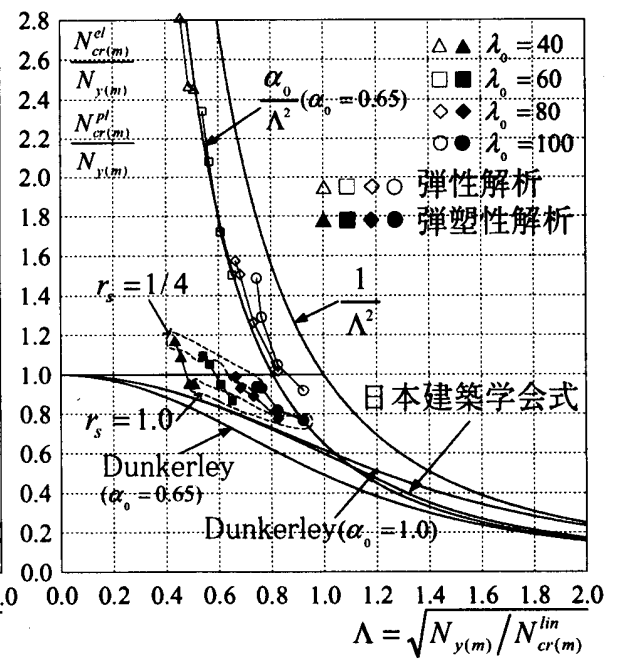

(c) $\theta_{0}=3.0^{\circ}$

图 9 偏載荷重の座屈軸力と正規化細長比 $\Lambda$ の関係 $(\gamma=0.5)$

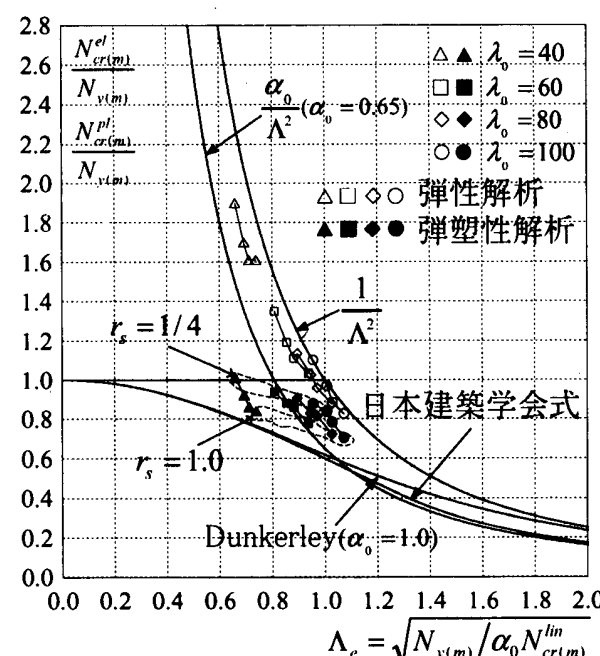

(a) $\theta_{0}=2.0^{\circ}$

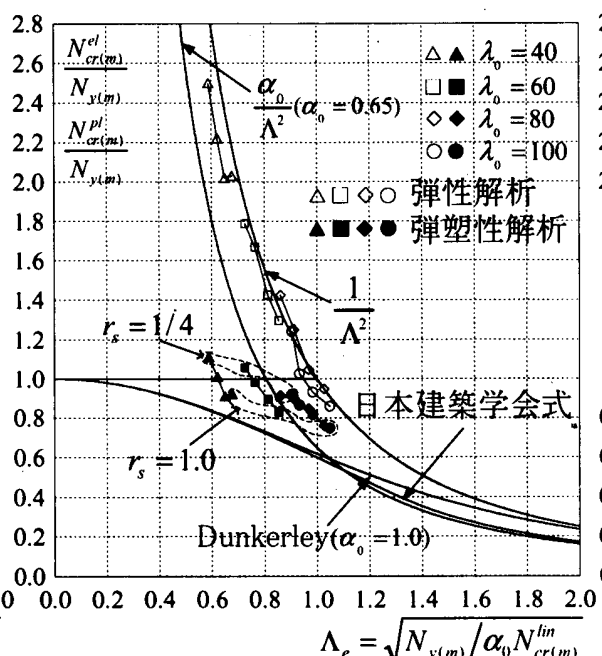

(b) $\theta_{0}=2.5^{\circ}$

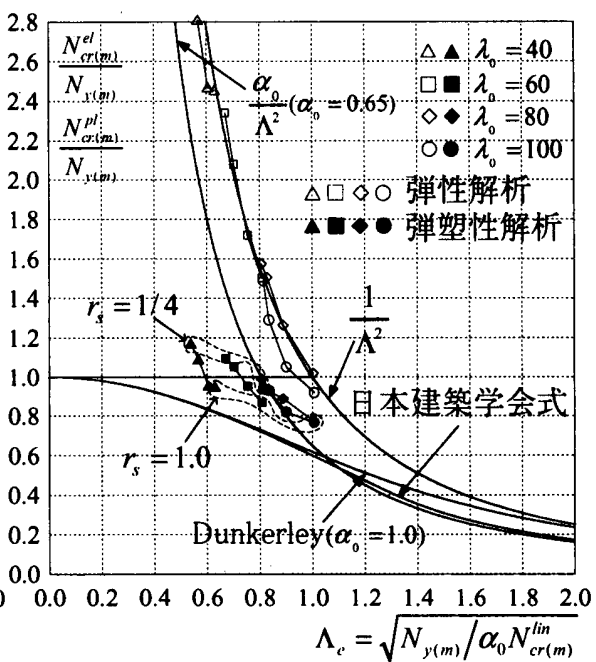

(c) $\theta_{0}=3.0^{\circ}$

図 10 偏載荷重の座屈軸力と正規化細長比 $\Lambda_{e}$ の関係 $(\gamma=0.5)$

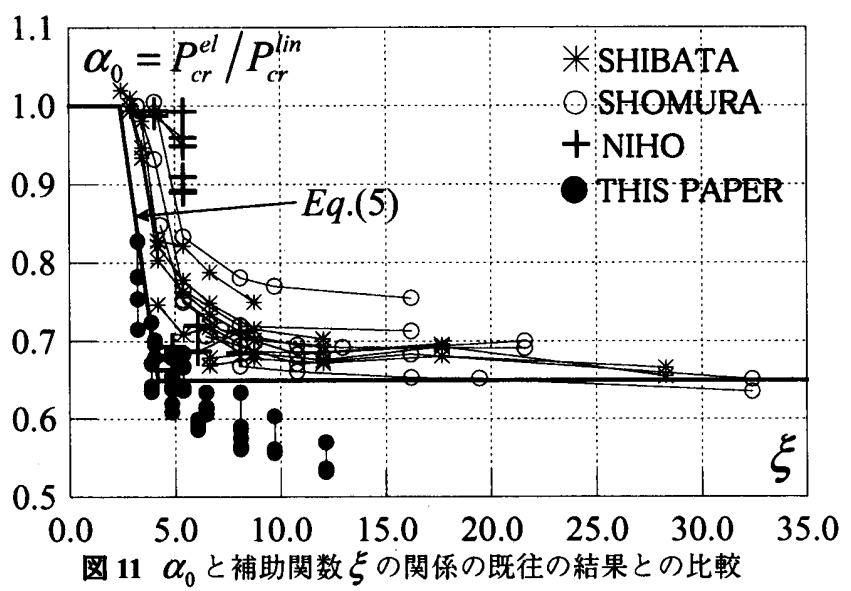

を描いてあるが, 弾塑性座屈解析結果は, 図 9 と同様にこの曲線の上 側に位置している。比較のために日本建築学会·鋼構造設計規準の短 期圧縮強度曲線を記入してあるが, 正規化細長比が 1.0 程度までは $\alpha_{0}=1.0$ とした修正 Dunkerley 式による曲線とほとんど隔たりがない,
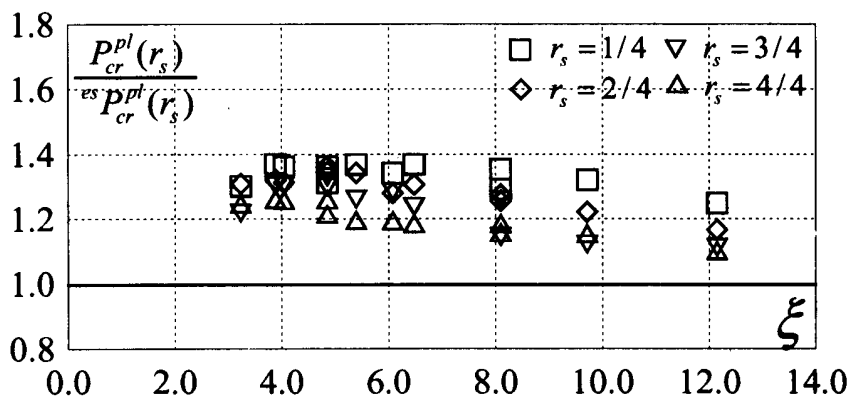

図 12 弾塑性座屈荷重の推定值と解析値の比と補助関数 $\xi$ の関係

1.0 以上では鋼構造設計規準式はわずかに修正 Dunkerley 式より低い。 したがって，鋼構造設計規準式により弾塑性座屈荷重を推定すると， $\Lambda_{e}$ が1.0より大きい領域では, その推定值は, 修正 Dunkerley 式よる 值より多少低く評価することとなる。

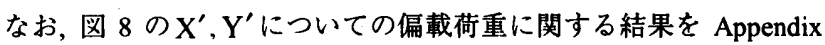
に示すが，X，Yについての荷重に対する結果とほほ同様な傾向とな っている事を付記し, 表 4 等に相当する詳細な結果は省略する。 


\section{6. 結論}

偏載荷重を受ける単層ラチスドームの断面算定法を検討するため の準備作業として, 部材半開角が $2.0^{\circ} \sim 3.0^{\circ}$, 部材細長比が 100 まで に限定して周辺ローラー支持のラチスドームの座屈荷重と座屈応力 度を検討した。得られた結果は,(あ) $r_{s}=1 / 4$ の偏載荷重による弾性 座屈荷重は, 等分布荷重時の線形座屈荷重の約 $50 \%$ であり, (い) $r_{s}$ の值にかかわらず, 弾性座屈荷重は, 式(5)の $\alpha_{0}$ の $80 \%$ の座屈低減係 数によりほほその下界を押えることができる。(う) 偏載荷重時の弾 塑性座屈応力度は, 等分布のそれよりも多少高めの值となるが, 弾塑 性座屈荷重は，式(3a)と(5)の等分布時の座屈応力度曲線で代替でき， かつ, 安全側に推定できる，とまとめられる。

今後は，等分布と偏載分布など複数の荷重を対象とする断面算定 法，部材に中間荷重がある場合の断面算定法など, 断面算定法の実用 化に向けた研究を進める予定である。

\section{感謝}

本研究は, 平成 9 年度の豊橋技術科学大学·学|内プロジェクト研究「アルミ型 押し材を用いた単層ラチスドームの座㖇酎力推定に関する研究にとして開始さ れた研究の内, 酎力評価に関する成果であり，其间研究者，故半谷裕彦博士， 高山誠博士, 山田聖志博士，高鳥英幸博士，，中田捷夫博士ににご指導を睗りまし た。ここに厚くお礼肿し.ドザます。

\section{参考文献}

1) 日本建筑学:会シェル空間構造運営委員会スペースフレーム小委員会：単届 シチスドームの安这解析ーその現状と問題点，日本建築学会, 1989.8

2) 加藤史郎, 柴田良; 植木隆司：㓮接合単層ラチスドームの座屈荷重推定 法一部材の坐屈応度を用いる方法: 日本建築学会構造系論文報告集, 第 436 号, pp91-103, 1992.6

3）大沢和雅, 山田大彦：分布荷重を受ける㴊接合単層ラチスドームの弾塑性 耐力-その 1 形状初期不整及び偏載荷重の影篅：日本建築学会学術講演梗概 集(近畿), pp1105-1106, 1996.9

4) 加藤史郎, 村村昌版, 柴田良一, 植木隆司：円形平面を有する単層ラチスド 一ムの座䲩荷重の推定：日本建築学会構造系論文報告集, 第 439 号, pp111$119,1992.9$

5) 柴田良一, 加藤史郎, 植木隆司：きわめて偏平な㓮接合単層ラチスドーム の弾塑性座屈荷重一等分布荷重を受ける周辺ピン支持 6 角形平面ドームの 弹塑性座烕応力度曲線について：日本建築学会構造系論文報告集, 第 449 号, pp143-153, 1993. 7

6) 加藤史郎，松永靖. ., 仁保 裕, 弾性 2 次解析を用いた単層ラチスドームの断 面算定法についてい一考察：日本建築学会棈造系論文報告集, 第 526 号, pp93-100, 1999.12

7) 仁保裄 ：単層ラチースドームの部材断面算定法の関する研究一部材断面を 算定する際に用いる係数の設定法について 一, 豊楀技術科学大学大学院工 学研究科 修士十論文, 2000.1

\section{APPENDIX}

偏載荷重を受けるドームの座屈荷重が等分布の場合とどう異なる かを分析するための偏載荷重条件として，図 8 の偏載荷重以外に図 A1 の偏載荷重も考えられる。等分布荷重で断面算定されたラチスド 一ムの管厚分布は図6に示したように, 稜線部材が他の部材より厚く なって, 偏載荷重の影響を検討するため部材半開角 $\theta_{0}$ は $2.0^{\circ}, 2.5^{\circ}$, $3.0^{\circ}$ について図 8 の偏載荷重中心に検討を行ったが, 図 A1 の偏載荷 重の結果は図 9,10の結果とほほ同じであり, 参考のため, 図 $\mathrm{Al}$ の偏 載荷重条件の場合の結果をここに $\theta_{0}=2.0^{\circ}$ のみ示す。

\section{1. 偏载荷重}

偏載荷重を受けるドームの偏載荷重の分布は図 $\mathrm{A} 1$ に示すものであ り,すべての条件は図 8 の解析モデルと同じものである。

\section{2. 偏截荷重を受けるドームの座屈応力度の分析}

弾塑性座屈荷重を特定部材 $(\mathrm{m})$ の座屈軸力に変換した座屈軸力と正 規化細長比の関係を図 8 の荷重と比較して図 A2 に示す。部材半開 角 $\theta_{0}$ と細長比 $\lambda_{0}$ にかかわらず，偏載度 $r_{s}$ に対する結果はほほ同様 の值であり, 図 8 と図 $\mathrm{Al}$ の偏載荷重の向には明暸な差はないと考え られる。

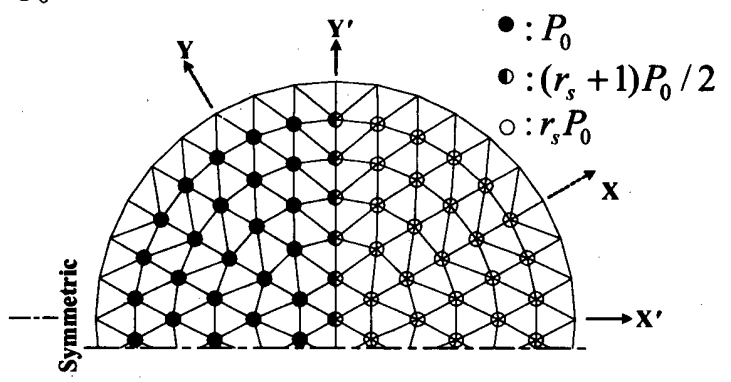

图 A1 偏載荷重の仮定 $\left(P_{0}=392 \mathrm{KN} /\right.$ node, $\left.r_{s}=1 / 4,2 / 4,3 / 4,4 / 4\right)$
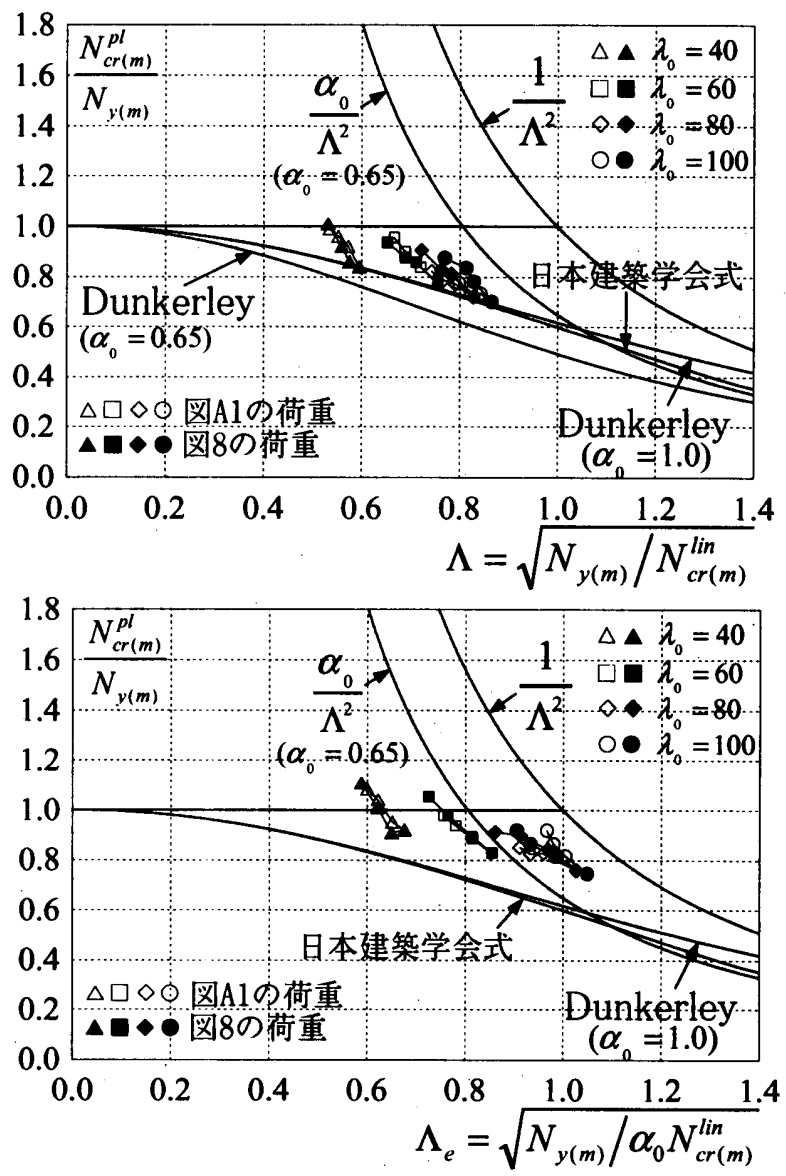

图 A2 編載荷重の座屈軸力と正規化細長比 $\Lambda$ と $\Lambda$ の関係 $\left(\theta_{0}=2.0^{\circ}, \gamma=0.5\right)$ 